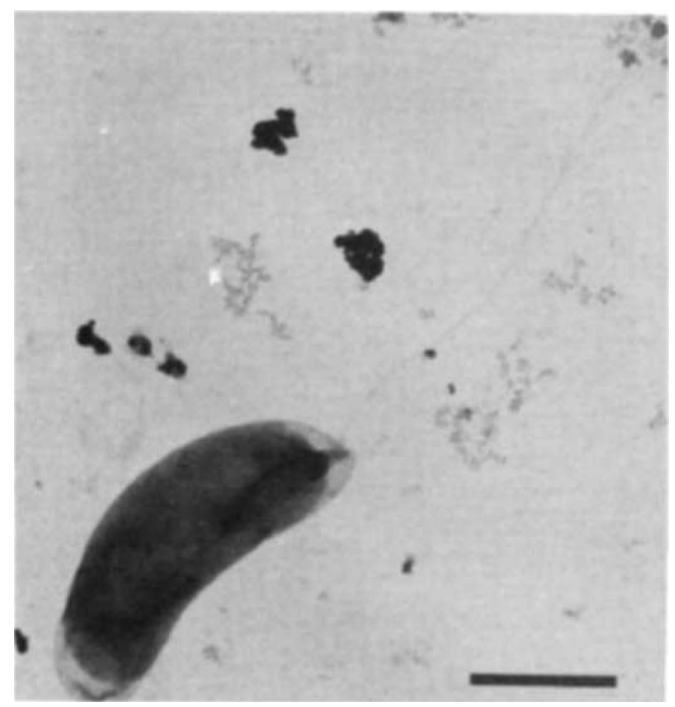

Fig. 1 Electron micrograph of a negatively-stained vibroid cell of strain MV-1. Note the single polar flagellum and the chains of intracellular electron-opaque magnetosomes. The bacterium was stained with $2 \%$ phosphotungstic acid. Bar, $0.5 \mu \mathrm{m}$.

\section{Anaerobic magnetite production by a marine, magnetotactic bacterium}

\author{
Dennis A. Bazylinski*, Richard B. Frankel $\dagger$ \\ \& Holger W. Jannasch*
}

*Department of Biology, Woods Hole Oceanographic Institution, Woods Hole, Massachusetts 02543, USA

$\dagger$ Francis Bitter National Magnet Laboratory, Massachusetts Institute of Technology, Cambridge, Massachusetts 02139, USA

Bacterial production of magnetite represents a significant contribution to the natural remanent magnetism of deep-sea and other sediments ${ }^{1-5}$. Because cells of the freshwater magnetotactic bacterium Aquaspirillum magnetotacticum require molecular oxygen for growth and magnetite synthesis ${ }^{6}$, production of magnetite by magnetotactic bacteria has been considered to occur only in surficial aerobic sediments ${ }^{7}$. Moreover, it has been suggested that deposits of single-domain magnetite crystals are palaeooxygen indicators presumably having been formed under predominantly microaerobic conditions ${ }^{5-8}$. In contrast, some nonmagnetotactic, dissimilatory iron-reducing bacteria, such as the recently described strain GS-15 by Lovley et al. ${ }^{7}$, synthesize extracellular magnetite from hydrous ferric oxide under anaerobic conditions. We now report the first isolation and axenic culture of a marine, magnetotactic bacterium, designated MV-1, that can synthesize intracellular, single-domain magnetite crystals under strictly anaerobic conditions. We conclude that magnetotactic bacteria do not necessarily require molecular oxygen for magnetite synthesis and suggest that they, as well as dissimilatory iron-reducing bacteria, can contribute to the natural remanent magnetism of even long-term anaerobic sediments.

Strain MV-1 was isolated from sulphide-rich sediment of an estuarine salt marsh near Boston, Massachusetts. Water samples from the site contained 23 p.p.t. salt. Cells were small (0.2-0.4 by $1-3 \mu \mathrm{m}$ ) with vibroid to helicoid morphology and were motile by means of a single, polar flagellum (Fig. 1). Based upon morphology, guanine-plus-cytosine $(G+C)$ content of the DNA

\footnotetext{
$\dagger$ Present address: Physics Department, California Polytechnic State University, San Luis
} Obispo, California 93407, USA.
( $53.5 \mathrm{~mol} \%$ ), and other characteristics, MV-1 does not appear to be closely related to $A$. magnetotacticum, presently the only other magnetotactic bacterium isolated in pure culture. Cells orientated and migrated along magnetic-field lines. Like bipolarly-flagellated magnetotactic spirilla ${ }^{9,10}$, an individual cell could migrate in either direction along the magnetic field lines and spontaneously reverse direction without turning around.

Cells of MV-1 oxidize organic acids and possibly certain amino acids anaerobically using nitrous oxide as terminal electron acceptor. Nitrous oxide is reduced to dinitrogen. To ensure the presence of anaerobic conditions, growth medium was boiled, cooled and dispensed under nitrogen gas passed over heated copper filings to remove oxygen. The medium was strongly redox buffered with $0.4 \mathrm{~g} \mathrm{l}^{-1}$ cysteine $\cdot \mathrm{HCl}$ and contained resazurin, a redox indicator that is colourless when reduced. Dinitrogen in culture bottles was replaced with nitrous oxide that was passed through a solution of alkaline pyrogallol to remove traces of contaminating oxygen ${ }^{11}$. All medium used in this study was colourless prior to and just after inoculation. Oxygen was not detected in the headspace of culture bottles by gas chromatography.

Cells grown under strictly anaerobic conditions in pre-reduced medium with nitrous oxide and $25 \mu \mathrm{M}$ ferric quinate, contained a chain of approximately ten iron-rich magnetosomes that longitudinally traversed the cell (Fig. 2a). Iron constituted about $1.6 \%$ of the dry weight of the cells, and was highly localized in the magnetosomes. Magnetite, $\mathrm{Fe}_{3} \mathrm{O}_{4}$, was identified as the principal component of the magnetosomes by Mössbauer spectroscopy of freeze-dried cells and extracted magnetosomes (Fig. $2 b$ ). Hydrous ferric oxide, presumably a precursor to magnetite precipitation $^{12}$, was also present. Cells are also able to grow microaerobically in semi-solid oxygen gradient cultures. Under these conditions, cells also behaved magnetotactically and contained an average number of eight magnetosomes per cell.

Individual magnetite particles were parallelepipeds with approximate dimensions $40 \times 40 \times 60 \mathrm{~nm}$. This volume is within the single-magnetic-domain size range for magnetite ${ }^{13}$. An average permanent magnetic dipole moment per cell of $\mathrm{M}=$ $2.1 \times 10^{-13}$ e.m.u. was determined by measuring the total magnetic moment of a suspension of a measured number of cells with a SQUID magnetometer at room temperature in applied fields of $10-100 \mathrm{Oe}$. This is sufficient for the magnetotactic response ${ }^{14}$. Bulk magnetic measurements on freeze-dried cells gave a saturation magnetization corresponding to $1.5 \%$ 

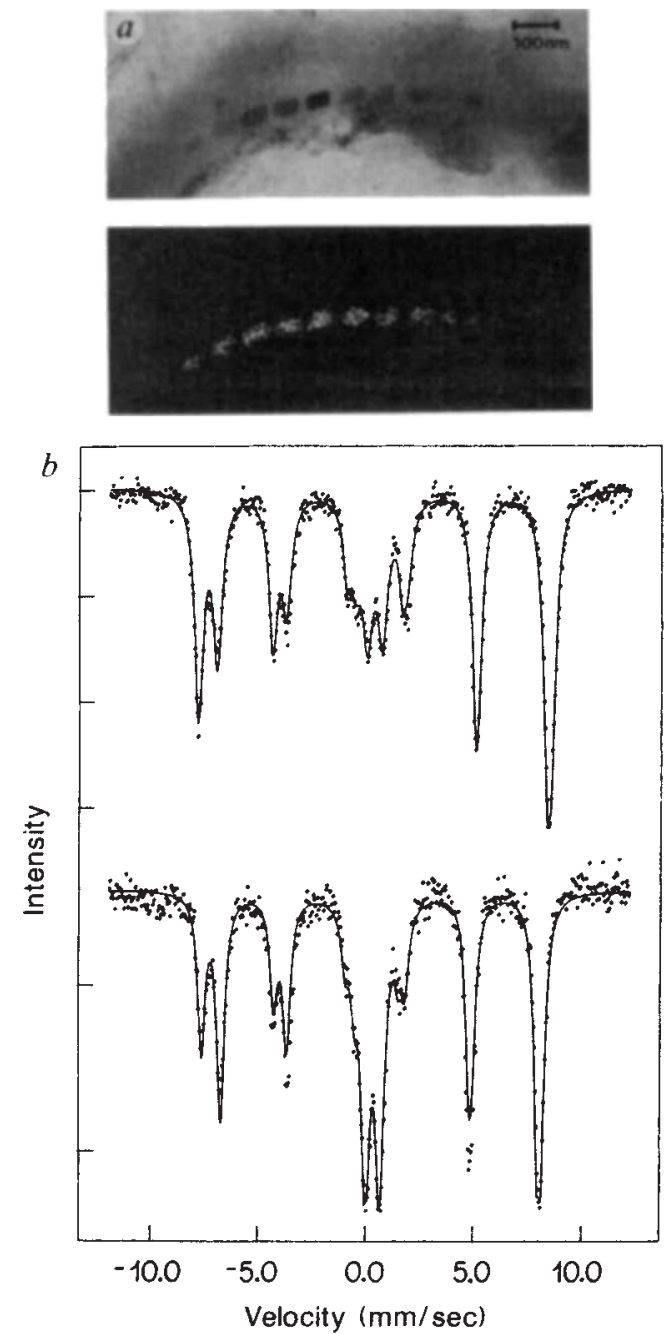

Fig. $2 a$, Transmission electron micrograph of a portion of a cell of MV-1 showing chain of 10 magnetosomes (top) and iron X-ray map of the same region (bottom) showing localization of iron in the cell. Bar, $100 \mathrm{~nm}$. $b$, Mössbauer spectra of extracted magnetosomes (top) and freeze-dried cells (bottom). The spectra correspond to $\mathrm{Fe}_{3} \mathrm{O}_{4}$ with some surface oxidation of extracted magnetosomes. The extra quadrupole doublet close to zero velocity in each spectrum is presumably due to a hydrous ferric oxide precursor to $\mathrm{Fe}_{3} \mathrm{O}_{4}$ precipitation. The solid line is a theoretical least-squares fit to the data.

magnetite per dry cell weight. The coercive force was 300 gauss and the remanent-to-saturation magnetization ratio approached 0.5 . These values are comparable with those for A. magnetotacticum ${ }^{15}$.

Karlin et al. ${ }^{16}$ showed that authigenic magnetite formation in suboxic marine sediments is confined between levels of nitrate reduction and iron reduction. Magnetotactic bacteria have not been considered the probable source of this magnetite, based on the molecular oxygen requirement of $A$. magnetotacticum for magnetite production. However, our results show that some marine magnetotactic bacteria can grow and synthesize singlemagnetic domain particles of magnetite in the absence of molecular oxygen.

The occurrence of nitrous oxide is common in marine sediments ${ }^{17-19}$, presumably as a product of bacterial denitrification when oxygen is absent or in very low concentrations ${ }^{20,21}$. For this reason, organisms like MV-1 could be common in marine sediments in the layers reported by Karlin et al. as being the site of authigenic magnetite production. Dissimilatory ironreducing bacteria could also contribute to the remanent magnetization of those sediments. However, the dissimilatory iron- reducing bacteria produce magnetite particles with a wide size distribution that is strongly peaked in the superparamagnetic size range, and therefore below the size required for stable, single-magnetic domains (D. R. Lovley and R. B. Frankel, unpublished data). Thus magnetotactic bacteria, with their uniform, stable, single-magnetic-domain-size particles could be the principal contributors to the natural remanence even in suboxic marine sediments.

We thank J. B. Waterbury, A. Garratt-Reed, E. R. Sholkovitz, D. G. Franks, F. W. Valois, C. D. Taylor, C. O. Wirsen, T. C. Hollocher and R. P. Blakemore for analytical expertise and discussions. We especially thank Dr B. L. Howes for nitrous oxide measurements which led to the isolation of MV-1. D.A.B. and H.W.J. were supported in part by the National Science Foundation and the Office of Naval Research. R.B.F. was partially supported by the Office of Naval Research. The Francis Bitter National Magnet Laboratory is supported by the National Science Foundation.

Received 23 March; accepted 13 June 1988.

1. Kirschvink, J. L. \& Chang, S.-B. R. Geology 12, 449-562 (1984).

2. Chang, S.-B. R. \& Kirschvink, J. L. in Magnetite Biomineralization and Magnetoreception in Organisms, (eds Kirschvink, J. L., Jones, D. S. \& MacFadden, B. J.) 647-669 (Plenum, New York, 1985).

3. Peterson, N., von Dobeneck, T. \& Vali, H. Nature 320, 611-615 (1986),

4. Stolz, J. F., Chang, S.-B. R. \& Kirschvink, J. L. Nature 321, 849-851 (1986).

5. Chang, S.-B. R, Stolz, J. F. \& Kirschvink, J. L. Phys. Earth planet Inter, 46, 289-303 (1987).

6. Blakemore, R. P., Short, K. A., Bazylinski, D. A., Rosenblatt, C. \& Frankel, R. B. Geomicrobiol. J. 4, 53-71 (1985).

7. Lovley, D. R., Stolz, J. F., Nord, G. L. Jr \& Phillips, E. J. P. Nature 330, 252-254 (1987).

8. Chang, S. B. R. \& Kirschvink, J. L. Geol. Soc. Amer. Bull. 16, 468 (1984).

9. Blakemore, R. P. A. Rev. Microbiol. 36, 217-239 (1984)

10. Spormann, A. \& Wolfe, R. S. FEMS Lett. 22, 171-177 (1984).

11. Hawk, P. B., Oser, B. L. \& Summerson, W. H. Practical Physiological Chemistry, 13th edn, 1321 (Blakiston, New York, 1954).

12. Frankel, R. B., Papaefthymiou, G. C., Blakemore, R. P. \& O'Brien, W. Biochim. biophys. Acta 763, 147-159 (1983).

13. Butler, R. F. \& Banerjee, S. K. J. geophys. Res. 80, 4049-4058 (1973).

14. Frankel, R. B. \& Blakemore, R. P. J. Magn. magn. Mater. 15-18, 1562-1564 (1980).

15. Moskowitz, B., Frankel, R. B., Flanders, P., Blakemore, R. P. \& Schwartz, B. B. J. Magn. magn. Mater. (in the press).

16. Karlin, R., Lyle, M. \& Heath, G. R. Nature 326, 490-493 (1987)

17. Seitzinger, S., Nixon, S., Pilson, M. E. Q. \& Burke, S. Geochim. cosmochim. Acta 44 , $1853-1860(1980)$.

18. Seitzinger, S. P., Pilson, M. E. Q. \& Nixon, S. W. Science 222, 1244-1246 (1983).

19. Seitzinger, S. P., Nixon, S. W. \& Pilson, M. E. Q. Limnol. Oceanogr. 29, 73-83 (1984).

20. Sørensen, J. Appl, envir. Microbiol. 36, 809-813 (1978).

21. Jørgensen, K. S., Jensen, H. B. \& Sørensen, J. Can. J. Microbiol. 30, 1073-1078 (1984) 